\title{
ЗДОРОВ’Я МОЛОДІ - ЗАПОРУКА НАШОГО МАЙБУТНЬОГО
}

\author{
О. В. Оксютенко
}

\section{Київський міський медччний коледж}

У статті висвітлено проблеми, з якими стикається молодь ХХІ століття, та оптимальні шляхи, які максимально наближають суспільство до вирішення проблем молодого покоління.

\section{YOUTH HEALTH - THE KEY TO OUR FUTURE \\ o. V. Oksytenko}

\section{Kyiv Municipal Medical College}

The article highlights the problems faced by the youth of the XXI century. And the way that approximates a society to solve problems of the young generation.

Вступ. Здоров'я - найбільший дар природи. Ф. Бекону належить вислів: «перший обов'язок медицини зберігати здоров'я, другий - лікувати хвороби». На всіх етапах розвитку суспільства життя людини проходило у протиборстві з хворобами, що знайшло відображення у пошуках засобів лікування та розвитку народної медицини. Це було першим стимулом наукового пізнання сутності індивідуального здоров'я людини.

Однак і давнє мистецтво лікування, й сучасна клінічна медицина здебільшого обмежувалися не стільки логічним, скільки інтуїтивним розумінням здоров'я як стану благополуччя.

Сьогодні здоров'я вже не розглядають як суто медичну проблему, до того ж, медичні питання становлять лише невелику частину феномену здоров'я.

Здоров'я нації в наш час розглядається як показник цивілізованості держави, що відображає соціально-економічне становище суспільства. Згідно з резолюцією ООН, здоров'я населення вважається головним критерієм доцільності та ефективності всіх людей без винятку.

Зрозуміло, що виховання свідомого та відповідального ставлення до здоров'я має починатись 3 раннього дитинства, поступово входити до системи світогляду, ставати складовою частиною загальної культури, духовного світу людини. Саме виховання зумовлює поведінку, стиль життя і, врешті-решт, стан здоров'я. Змінюватися ніколи не пізно, адже можливості організму людини не вичерпні.

(с) О. В. Оксютенко, 2015
Незаперечним фактом $є$ те, що спосіб життя кожної людини формується в молодому віці. Очевидно, що запровадження здорового способу життя може позитивно вплинути на стан здоров'я не лише дітей і молоді, а й усього населення країни.

Основна частина. За оцінками фахівців, близько $15 \%$ хвороб у дорослих $\epsilon$ наслідком умов життя в дитячі та в молоді роки [1].

Стало звичним, що людина, яка ніколи не хворіє, безтурботно ставиться до свого здоров'я. Тіло безвідмовно служить як цілісний механізм, і людина не уявляє, що може бути інакше. Здорові люди сприймають свій стан не задумуючись, так, ніби нічого не може трапитись і ніяка хвороба їх не здолає. А ті, які перенесли серйозне захворювання, як правило, поводять себе інакше, вони відчувають, що про здоров'я потрібно піклуватися.

Вчені дослідили, якщо здоров'я людини взяти за $100 \%$, то приблизно на 10 \% воно залежить від успішного функціонування системи охорони здоров'я, на 20 \% - від спадковості, на 20 \% - від соціоекологічних факторів, але найбільше - на 50 \% - від способу життя людини.

Проблема збереження і зміцнення індивідуального здоров'я населення набуло останнім часом актуальності в усьому світі. Значною мірою це стосується й України. Українська нація в своєму історичному розвитку за рівнем здоров'я досі відстає від передових країн світу. Природно, що особливу турботу викликає здоров'я молодого покоління - найперспективнішої частини суспільства [2]. 
Вчені-медики б'ють на сполох з приводу погіршення стану здоров'я молодих людей. Як заявили на засіданні вченої ради МОз України 2014 року, в молодого покоління спостерігається динаміка зростання несприятливих показників, а саме: перехід гострих хвороб у хронічні, збільшується кількість молоді з патологіями (гіпертонічна хвороба, виразкова хвороба шлунка, ожиріння тощо), що раніше були характерні лише для дорослих. Здоровими можна вважати близько 10 \% молоді. Серед тих, хто вступає у доросле життя, 40-50\% мають морфофункціональні відхилення, а 40-60 \% - хронічні захворювання. Частота анемій за п'ять останніх років зросла майже на $400 \%$, а новоутворень - більшякна 130\%. Погіршення стану здоров'я молоді підтверджують такі показники: хвороби органів дихання мають майже 33 \% молоді, нервової системи та органів чуття - 17,4\%, органів травлення - 9,7\%, кістково-м'язової системи - 9,8 \%. Як показав аналіз, ознаки цих захворювань виявляються ще в дитячому віці. Наприклад, короткозорість - у 83 \%, захворювання центральної та периферійної нервової системи у $73 \%$, виразкова хвороба - у 55,4\% [3, 4].

особливе занепокоєння викликає стан репродуктивного здоров'я дівчат, їхні захворювання на 10-15\% перевищують аналогічні показники уюнаків, іє невід'ємною складовою частиною здоров'я нації в цілому.

Щорічноу репродуктивний період вступає 13-14 тисяч дівчат із тяжкою соматичною патологією, в тому числі з порушеннями функції статевої системи. Це зумовлює тенденцію до збільшення викиднів, зростання рівня материнської та дитячої смертності. Ці показники значно перевищують середньоєвропейські. Однією із причин цих порушень є проблема низького рівня знань у сфері статевого виховання (понад 80 \% молоді катастрофічно не вистачає знань у сфері статевого виховання).

Такий стан зумовлює необхідність подальшого здійснення комплексу заходів, спрямованих на поліпшення репродуктивного здоров'я підлітків. Також зросла кількість підлітків, які мають пограничні стани та належать до групи підвищеного медикосоціального ризику [5].

За останній час значно турбує поширення таких соціально зумовлених захворювань, як туберкульоз, гонорея, сифіліс, ВІл-інфекція тощо. Недосконала система реєстрації не дає змоги об'єктивно оцінити усю гостроту проблеми. В цілому масштабне розповсюдження інфекцій, що передаються статевим шляхом, пов'язано, в нашій країні, з низькою сані- тарною культурою основної маси населення та соціальними катаклізмами.

Не залишає й байдужим й те, що в нашій країні нараховується 18 тисяч молоді, які ще в дитячому віці залишились без батьківської опіки, і здоровими серед них учені вважають лише 4 \%. Причинами зниження якості здоров'я у таких дітей стають погіршення умов життя, виховання в неповних та деструктивних сім'ях, неповноцінне харчування, завчасна та неконтрольована сексуальна активність, поширення наркоманії, пияцтва та тютюнокуріння [3].

Здоров'я дітей - основа розвитку держави. Тому саме медичні аспекти збереження здоров'я мають істотно більше значення в дитинстві, ніж у подальших вікових групах. Більш того, питання здоров'я населення України в даний час трансформувалися у проблему, яка загрожує національній безпеці держави.

Покращити таке становище можна через застосування нового підходу до формування здорового способу життя, який би ґрунтувався на сучасному підході збереження здоров'я, тобто враховували всі його аспекти. Важливо також, щоб вони опиралися на активізацію участі в даному процесі молоді. Мова йде про те, щоб не дорослі ініціювали таку роботу, а сама молодь. Саме від їхньої активності й буде залежати успішність поширення формули: «здоровим бути модно, стильно і красиво».

Процес виховання свідомого ставлення молоді до власного здоров'я, здоров'я інших людей здійснюється шляхом передачі знань і формування умінь та навичок зміцнення та збереження здоров'я, виконання практичних дій здорового способу життя.

Основними цілями роботи щодо пропаганди здорового способу життя є:

- формування позитивної мотивації щодо здорового способу життя культури здоров'я;

- знайомство молоді з основами здорового стилю життя, формування свого стилю здорового життя, здійснення профілактичної роботи за негативними проявами;

- формування теоретичних та практичних навичок здорового способу життя, формування творчої особистості здібної до саморозвитку, самоосвіти і самоактуалізації молоді.

Навчання здоровому способу життя повинно бути системним і сприяти гармонійному розвитку психофізичних здібностей молоді.

Визначено, що найпопулярнішими формами роботи щодо формування здорового способу життя в 
молодіжному середовищі стали такі інноваційні методики, як інтерактивні театри, молодіжні лекторські групи, спікерські бюро тощо. На даному етапі важливим досягненням $\epsilon$ заохочення певної категорії молоді до участі в програмах щодо дотримання здорового способужиття. В ході підготовки передбачаються заняття, спрямовані на розвиток тренерських та лекторських навичок. До роботи з волонтерами повинні залучатися провідні спеціалісти: лікарі, педагоги, представники державних і недержавних організацій, які займаються профілактичною роботою.

Молодь необхідно розглядати як активну суспільну силу і стратегічний ресурс розвитку України. Це в сучасних умовах вимагає виділення молодіжної політики як одного з основних загальнонаціональних пріоритетів.

В цілому, сучасна ситуація в державі та суспільстві вимагає негайних заходів, спрямованих на формування цілісної стратегії соціально-економічного, політичного й культурного розвитку України, що припускає послідовну реалізацію заходів довгострокового характеру, спрямованих не тільки на збереження рівня життя населення, але й на суттєве підвищення соціальних стандартів. Це системна робота, тому вимагає особливих зусиль:

- приділення уваги активізації здорового способу життя молоді шляхом проведення заходів із питань попередження наркоманії та негативних наслідків вживання наркотиків, запобігання поширенню

\section{ЛITEРАТУРА}

1. Підаєв А. В. Панорама охорони здоров'я України / А. В. Підаєв, О. Ф. Возіанов. - К. : Здоров'я, 2005. С. 295-297.

2. Бондар Т. В. Формування здорового способу життя молоді / Т. В. Бондар, О. Г. Карпенко. - К. : Український інститут соціальних досліджень, 2005. - С. 5.

3. Яременко О. О. Формування здорового способужиття молоді: стратегія розвитку українського суспільства : Ч. 1 / О. О. Яременко. - К. : Державний інститут проблем сімі та молоді, 2009. - С. 61-63. соціально-небезпечних хвороб, насамперед туберкульозу та ВІЛ/СНІДу, здійснення інформаційнопросвітницької діяльності серед молоді з питань шлюбних відносин, планування сім'ї, виховання здорової дитини, наслідків вживання алкоголю;

- застосування нових форм роботи з молоддю із використанням ресурсів мережі «Internet», засобів масової інформації (проведення телевізійних форумів, ве6-форумів, он-лайн конференцій та ін.) з метою масового охоплення цільової аудиторії, утворення можливостей прямого спілкування з експертами, висловлення громадської думки тощо;

- постійне вживання заходів щодо забезпечення сезонного оздоровлення молоді, розвитку молодіжного туризму, зокрема;

- залучення молоді доучасті вкультурно-мистецьких дозвільних заходах, спрямованих на формування у свідомості молоді притаманних українському народові моральних цінностей, розвитку і підтримки традицій вшанування сімейних цінностей [6].

Висновок. Одна з найактуальніших проблем сьогодення - «омолодження» Хвороб та збільшення кількості молоді, які належать до групи підвищеного медико-соціального ризику. I тільки, кропітка робота, яка повинна ґрунтуватися на використанні найбільш ефективних новітніх форм пропаганди і агітації, в якій буде брати участь сама молодь, зможе сповільнити або призупинити процес вироджування нації.

4. Романова Н. Ф. Молодь за здоровий спосіб життя / Н. Ф. Романова. - К. : Міністерство України у справах сім'і, молоді та спорту, 2010. - С. 38-41.

5. Гулий І. С. Основи валеології / І. С. Гулий, Г. О. Сімахіна. - К. : НУХТ, 2009. - С. 77-80.

6. Молоді України - здоровий спосіб життя [Електронний ресурс]. - Режим доступу : http://www.experts.in.ua/ 